\title{
Outflow occlusion for circulatory arrest in dogs ${ }^{1}$
}

\author{
James N.B.M. de Andrade ${ }^{2 *}$, Angelo J. Stopiglia ${ }^{3}$, Denise T. Fantoni ${ }^{3}$, \\ Maria C. Abduch ${ }^{4}$ and Marcia Kahvegian ${ }^{5}$
}

\begin{abstract}
Andrade J.N.B.M., Stopiglia A.J., Fantoni D.T., Abduch M.A. \& Kahvegian M. 2009. Outflow occlusion for circulatory arrest in dogs. Pesquisa Veterinária Brasileira 29(2):137-142. Hospital Veterinário, Universidade de Franca, Av. Dr. Armando Salles Oliveira 201, Franca, SP 14404-600, Brazil. E-mail: jamescardio@terra.com.br

The purpose of this study was to evaluate the possibility of producing circulatory arrest by occlusion of the pulmonary trunk as an alternative to the venous inflow occlusion through the left hemithorax. Eight healthy mongrel dogs were divided in two groups. Group I underwent 4 minutes of outflow occlusion and Group II was submitted to 8 minutes of circulatory arrest. Outflow occlusion was performed through left thoracotomy and pericardiotomy by passing a Rumel tourniquet around the pulmonary trunk. Physical examination, electrocardiography, echocardiography, blood gas analyses, hemodynamic, and oxygen transport variables were obtained before and after the procedure. The dogs from Group I did not have any clinical, electrocardiographic, echocardiographic, or hemodynamic abnormalities after anesthetic recover. In the Group II, only one dog survived, which had no clinical, electrocardiographic, or echocardiographic abnormalities. In this last dog, just after releasing the occlusion, it was detected increases in the following parameters: heart rate (HR), systolic, diastolic and mean arterial blood pressure (SAP; DAP; MAP), pulmonary artery pressure (PAP), pulmonary wedge pressure (PWP), central venous pressure (CVP), cardiac output (CO), systolic index (SI), cardiac index (Cl), left and right ventricular stroke work (LVSW; RVSW), oxygen delivery index $\left(\mathrm{DO}_{2}\right)$, oxygen consumption index $\left(\mathrm{VO}_{2}\right)$, and oxygen extraction $\left(\mathrm{O}_{2}\right.$ ext). Moreover, the oxygen content of arterial and mixed venous blood $\left(\mathrm{CaO}_{2} ; \mathrm{CvO}_{2}\right)$, and the arterial and mixed venous partial pressure of oxygen $\left(\mathrm{PaO}_{2} ; \mathrm{PvO}_{2}\right)$ were decreased 5 minutes after circulatory arrest. Outflow occlusion is a feasible surgical procedure for period of 4 minutes of circulatory arrest.
\end{abstract}

INDEX TERMS: Outflow occlusion, circulatory arrest, dogs.

\footnotetext{
${ }^{1}$ Received on December 12, 2007.

Accepted for publication on November 7, 2008.

The research was supported by Fundação de Amparo à Pesquisa no Estado de São Paulo (FAPESP).

${ }^{2}$ Hospital Veterinário, Programa de Mestrado em Cirurgia e Anestesiologia Veterinária, Universidade de Franca, Rua Dr. Armando Salles Oliveira 201, Parque Universitário, Franca, SP 14404-600, Brazil. *Autor para correspondência: jamescardio@terra.com.br

${ }^{3}$ Departamento de Cirurgia, Faculdade de Medicina Veterinária e Zootecnia (FMVZ), Universidade de São Paulo (USP), Av. Prof. Dr. Orlando Marques de Paiva 87, São Paulo, SP 05508-270, Brazil.

${ }^{4}$ Doutoranda do Instituto do Coração (InCor), Faculdade de Medicina, USP, Av. Dr. Enéas de Carvalho Aguiar 44, São Paulo, SP 05403000.

${ }^{5}$ Doutoranda do Programa de Pós-Graduação em Anestesiologia, Faculdade de Medicina, USP, Av. Dr. Enéas de Carvalho Aguiar 155, 80 andar, Bloco 3, São Paulo, SP 05403-000.
}

RESUMO.- ["Outfow occlusion" para parada circulatória em cães.] O objetivo deste estudo foi avaliar a possibilidade de se produzir uma parada circulatória pela oclusão do tronco pulmonar, como alternativa ao "inflow occlusion", pelo hemitórax esquerdo. Oito cães sem raça definida foram divididos em dois grupos. O Grupo I foi submetido a quatro minutos de parada circulatória e o Grupo II, a 8 minutos de parada. Realizou-se o "outflow occlusion" por meio de toracotomia intercostal esquerda e pericardiotomia, passando-se um torniquete de Rumel ao redor do tronco pulmonar. Foram realizados exame físico, eletrocardiografia, ecocardiografia, hemogasometria, avaliação hemodinâmica e cálculo de variáveis de transporte de oxigênio, antes e após o procedimento. Os cães do Grupo I não sofreram alterações clínicas, eletrocardiográficas, ecocardiográficas e hemodinâmicas após a recuperação anestésica. No Gru- 
po II, apenas um animal sobreviveu, sem apresentar alterações clínicas, eletrocardiográficas e ecocardiográficas. Neste cão, após a liberação do torniquete, houve aumento nas seguintes variáveis: freqüência cardíaca, pressões arteriais sistólica, média e diastólica, pressão arterial pulmonar, pressão da artéria pulmonar ocluída, pressão venosa central, débito cardíaco, índice sistólico, índice cardíaco, trabalho ventricular esquerdo e direito, índice de transporte de oxigênio, índice de consumo de oxigênio e taxa de extração de oxigênio. $O$ conteúdo de oxigênio arterial e venoso misto e a pressão parcial de oxigênio arterial e venosa mista diminuíram, cinco minutos após a parada circulatória. Concluiu-se que o "outflow occlusion" é um procedimento viável para a realização de parada circulatória por um período de quatro minutos.

TERMOS DE INDEXAÇÃO: Oclusão do tronco pulmonar, parada circulatória, cães.

\section{INTRODUCTION}

Cardiac surgeries can be performed in dogs by closed or opened procedures. Open-heart surgery requires that circulation must be arrested during the procedure by either venous inflow occlusion or cardiopulmonary bypass (Orton 1997).

Inflow occlusion is a technique in which all the venous flow to the heart is temporarily interrupted (Orton 1997). It can be performed through either a left or right thoracotomy, or a median sternotomy. Although inflow occlusion is more difficult to be performed, it can be accomplished through a left thoracotomy (Orton 1995). On the other hand, the pulmonary trunk can be readily accessed through a left thoracotomy. Thus, authors propose that the occlusion of the pulmonary trunk could cause an interruption of the blood flow from the right ventricle and consequently a circulatory arrest. Therefore, the left chambers could be opened and brief surgical procedures involving the mitral valve could be accomplished.

At the authors' knowledge, there is no publication regarding outflow occlusion at indexed literature. Thus, the purposes of the study reported herein were to evaluate the possibility of performing the technique of outflow occlusion, and verify the consequences of this procedure on the organism.

\section{MATERIALS AND METHODS}

Animals. Eight adult mixed-breed dogs (mean \pm SE body weight, $15.0 \pm 3.0 \mathrm{~kg}$ ) were evaluated to ensure that the dogs were healthy and the cardiac size and function were normal. Evaluations included physical examination, electrocardiography, CBC, serum biochemical analysis, and echocardiography. The study was approved by the institutional ethics committee, and all dogs received humane care in compliance with the established experimental principles ${ }^{6}$. Dogs were housed in an appropriative environment with adequate ventilation and illumination designed to fulfill their physiologic and behavioral needs. Dogs received commercial food twice a day, and water was available ad libitum.
Experimental groups. The dogs were divided in two groups of four animals. Group I underwent four minutes of outflow occlusion and Group II was submitted to 8 minutes of circulatory arrest.

Clinical evaluation. The dogs were evaluated by physical examination, including rectal temperature, color of mucous membranes, capillary refill time, femoral pulse, heart and respiratory rate, cardiopulmonary auscultation, and neurological exam. The neurological evaluation involved the assessment of the level of consciousness and behavior status, the position of the head and neck, the attitude and posture, the proprioceptive position, and the cranial nerves test (Chrisman 1985). A Small Animal Coma Scale, modified from Glasgow Coma Scale (Shores 1983), was also utilized for evaluating the neurological status after the ischemia caused by the circulatory arrest. This scale is designed to assist the clinician in evaluating neurologic status of craniocerebral trauma patients and the scores range from 3 to 18. As a guideline, a consistent total score of 3 to 8 represents a grave prognosis, 9 to 14 a poor to guarded prognosis and 15 to 18 a good prognosis (Shores 1983). The examination was performed one day before the surgery and one, two, and seven days after the procedure.

Electrocardiography. Electrocardiography was performed one day before surgery, and two and seven days after surgery, as described elsewhere (Tilley 1992). During the surgery the heart rate $(\mathrm{HR})$ and rhythm were obtained from the multiparametric monitor ${ }^{7}$.

Echocardiography. The echocardiography was performed one day before surgery, and two and seven days after surgery. The measurements were performed as described previously (Lombard 1984), referring to the transverse diameter of aorta (Ao) and left atrium (LA), the Ao/LA ratio, the left ventricular systolic and diastolic diameter, the shortening fraction (SF), and the ejection fraction (EF). The pulmonary pressures were estimated by the pulsed-wave Doppler and the cardiac valves function was evaluated by the color Doppler (Abduch 2004).

Hemodynamics. The hemodynamic variables were measured during the surgery immediately before the occlusion of the pulmonary trunk (baseline), five minutes (M1), and 30 minutes after releasing the tourniquet (M2). These variables were not measured during the circulatory arrest due to absence of blood flow at that moment. The oxygen saturation $\left(\mathrm{SpO}_{2}\right)$ was obtained by pulse oximeter ${ }^{8}$ attached to the tongue. The systolic, diastolic, and mean arterial blood pressures (SAP, DAP, MAP) were measured by a catheter introduced into the dorsal metatarsal artery connected to the pressure transducer of the pressure monitor?

A thermodilution catheter ${ }^{9}$ was introduced into the left jugular vein. Central venous pressure (CVP), pulmonary arterial pressure (PAP), pulmonary wedge pressure (PWP) and cardiac output (CO) were measured accordingly (Schoemaker \& Parsa 1995).

Oxygenation, ventilation and metabolic parameters. The oxygenation, ventilation, and the acid-basic balance were evaluated by arterial partial pressure of oxygen $\left(\mathrm{PaO}_{2}\right)$, arterial

${ }^{6}$ Guide to the Care and Use of Experimental Animals (provided by the Canadian Council on Animal Care, 315-350 Albert Street, Ottawa, Ontario K1R 1B1).

${ }^{7}$ Multiparametric monitor .Aligent Technologies, Böblingen, Germany.

8 Pulse oximeter model NPB 295, Nellcor Puritan Bennett Inc., Pleaseton, CA.

${ }^{9}$ Swan-Ganz catheter model K7F, Baxter Healthcare Corp., Irvine, CA. 
saturation of oxygen $\left(\mathrm{SaO}_{2}\right)$, arterial partial pressure of carbon dioxide $\left(\mathrm{PaCO}_{2}\right), \mathrm{pH}$, plasma bicarbonate $\left(\mathrm{HCO}_{3}{ }^{-}\right)$, and base deficit ${ }^{10}$.

Mixed venous blood was collected from the distal extremity of the pulmonary catheter to evaluate the mixed venous partial pressure of oxygen $\left(\mathrm{PvO}_{2}\right)$, mixed venous saturation of oxygen $\left(\mathrm{SvO}_{2}\right)$, mixed venous partial pressure of carbon dioxide $\left(\mathrm{PvCO}_{2}\right), \mathrm{pH}$, bicarbonate $\left(\mathrm{HCO}_{3}^{-}\right)$, and base deficit.

Calculated indexes. Stroke volume (SV), systolic index (SI), cardiac index $(\mathrm{Cl})$, left ventricular stroke work (LVSW), right ventricular stroke work (RVSW), systemic vascular resistance index (SVRI), pulmonary vascular resistance index (PVRI), oxygen delivery index $\left(\mathrm{DO}_{2}\right)$, oxygen consumption index $\left(\mathrm{VO}_{2}\right)$, oxygen content of arterial blood $\left(\mathrm{CaO}_{2}\right)$ and oxygen content of mixed venous blood $\left(\mathrm{CvO}_{2}\right)$, oxygen extraction $\left(\mathrm{O}_{2}\right.$ ext), and pulmonary shunt (Qs/Qt) were calculated by described formulas (Schoemaker \& Parsa 1995).

Anesthesia and analgesia. Dogs were pre medicated with meperidine ${ }^{11}(2 \mathrm{mg} / \mathrm{kg}, \mathrm{IM})$, and anesthesia was induced with propofol $^{12}(5 \mathrm{mg} / \mathrm{kg}, \mathrm{IV})$ and maintained by administration of a mixture of oxygen and isoflurane ${ }^{13}$ (expiratory end-tidal concentration of $1.4 \%$ ) via a rebreathing circuit ${ }^{14}$. Volumecontrolled ventilation was established with a tidal volume of $10 \mathrm{~mL} / \mathrm{kg}$. Respiratory rate were adjusted for keeping $\mathrm{ETCO}_{2}$ between 30 and $40 \mathrm{~mm} \mathrm{Hg}$. Muscular blockade was accomplished by administrating rocuronium ${ }^{15}(0.6 \mathrm{mg} / \mathrm{kg}$, IV). Fentanyl ${ }^{16}(5 \mathrm{~g} / \mathrm{kg}$ IV) was administered as a slow bolus five minutes before skin incision. Intercostal nerve block with bupivacaine ${ }^{17}(0.5 \mathrm{mg} / \mathrm{kg})$ was performed at the end of surgery, and ketoprofen ${ }^{18}\left(2 \mathrm{mg} / \mathrm{kg}\right.$, IM once daily), dipirona ${ }^{19}(25 \mathrm{mg} / \mathrm{kg}$, $\mathrm{SC}$, q $8 \mathrm{~h})$, and morphine sulfate ${ }^{20}(0.3 \mathrm{mg} / \mathrm{kg}$, IM, q $6 \mathrm{~h})$ were initiated 20 minutes before the end of the surgery.

Surgical procedure. Dogs were positioned in right lateral recumbence. Thoracotomy via the fourth intercostal space on the left side and pericardiotomy were performed. The pulmonary trunk was visualized and isolated with a right angle clamp. A cardiac tape was passed around the pulmonary trunk, making a Rumel tourniquet (Fig.1). The circulatory arrest was accomplished by closing the tourniquet, and the ventilation was discontinued. Circulatory arrest took four minutes for Group I and eight minutes for Group II. At the end of the scheduled time,

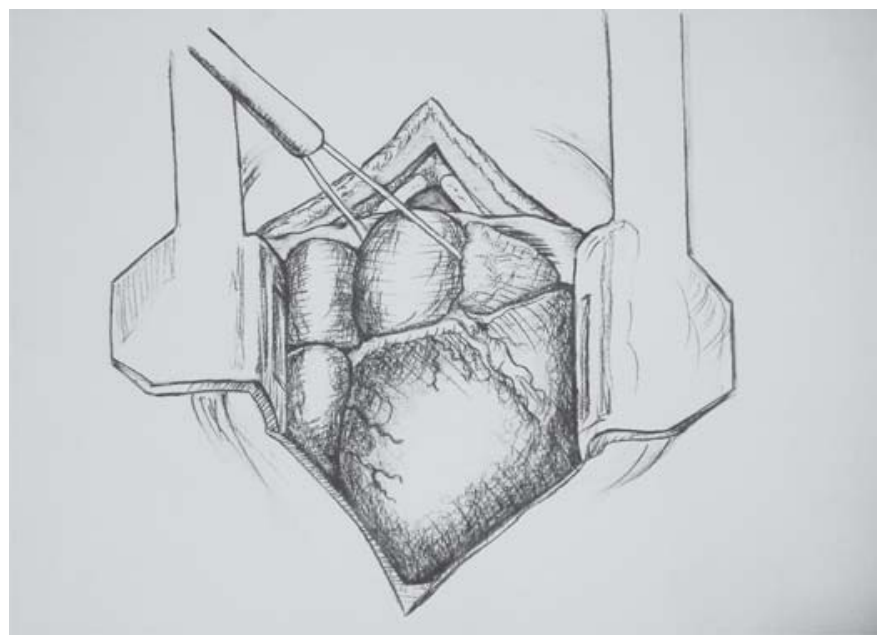

Fig.1. Outflow occlusion is performed from a left thoracotomy and pericardiotomy by passing a tourniquet around the pulmonary trunk. the tourniquet was released and the circulation was reestablished. Thoracic cavity was closed in a routine manner and the air was removed through a chest tube connected to a bottle which functioned as an underwater seal.

Statistical analyses. Data from Group I are presented as median and quartiles and evaluated parameters from the single survivor from Group II are presented as individual values. The hypothesis of equality among the moments in Group I was analyzed using the Friedman non-parametric test (Rosner 1986). The significance level used was $5 \%$.

\section{RESULTS}

The access to the pulmonary trunk through left thoracotomy in the $4^{\text {th }}$ intercostal space and pericardiotomy was adequate by allowing the correct placement of the Rumel tourniquet.

Mean sanguineous temperature was $36^{\circ} \mathrm{C}$ during the surgical procedure.

All animals from Group I (underwent four minutes of circulatory arrest) survived and recovered from anesthesia without clinical, electrocardiographic, and echocardiographic alterations in the pos-operative period (2 and 7 days after surgery). All dogs presented 18 points in the Small Animal Coma Scale 24 hours after the surgery. During the anesthetic monitoring, one dog from Group I had severe sinus bradycardia after releasing the pulmonary occlusion which was resolved by administering epinephrine $^{21}(0.01 \mathrm{mg} / \mathrm{kg}$, in bolus IV). Other dog had cardiac arrest at four minutes of outflow occlusion. Sinus rhythm was reestablished after gentle cardiac massage and application of epinephrine ${ }^{21}(0.01 \mathrm{mg} / \mathrm{kg}$, in bolus IV). The other dogs from this group maintained a sinus rhythm during the procedure.

In Group II (eight minutes of circulatory arrest) only one dog survived, without clinical, electrocardiographic, and echocardiographic alteration after the procedure. This dog received cardiac massage and epinephrine ${ }^{21}(0.01 \mathrm{mg} /$

10 Gasometer model ABL 5, Radiometer Medical A/S, Copenhagen, Denmark.

${ }^{11}$ Meperidine (Dolosal, Cristália Produtos Químicos Farmacêuticos Ltda, Itapira, SP, Brazil).

12 Propofol (Propovan, Cristália Produtos Químicos Farmacêuticos Ltda, Itapira, SP, Brazil).

13 Isoflurane (Isoforine, Cristália Produtos Químicos Farmacêuticos Ltda, Itapira, SP, Brazil).

142700 Shogum Evolution Anesthesia Device,

Takaoka, Nippon.

15 Rocuronium (Esmeron, Organon Teknika B.V., Boxtel, Netherlands).

16 Fentanyl (Fentanest, Cristália Produtos Químicos Farmacêuticos Ltda, Itapira, SP, Brazil).

17 Buivacaine (Neocaína 0,5\%, Cristália Produtos Químicos Farmacêuticos Ltda, Itapira, SP, Brazil).

${ }^{18}$ Ketoprofen (Ketofen. Merial Saúde Animal Ltda. Paulínia, SP, Brazil).

19 Dipirona (Dipirona. Laboratório Ibasa Ltda. Porto Alegre, RS, Brazil).

${ }^{20}$ Morphine sulfate (Dimorf. Cristália Produtos Químicos Farmacêuticos Ltda. Itapira, SP, Brazil).

21 Epinephrine (Adren - Hipolabor Farmacêutica Ltda.

Sabará, MG, Brazil). 
Table 1. Median and quartiles of $\mathrm{pH}, \mathrm{PaO}_{2}, \mathrm{PaCO}_{2}, \mathrm{SaO}_{2}, \mathrm{HCO}_{3}{ }^{-}$, and base deficit (BD) from arterial blood of dogs submitted to four minutes of outflow occlusion at baseline and five minutes (M1) and 30 minutes (M2) after procedure

\begin{tabular}{|c|c|c|c|c|c|c|c|c|c|}
\hline \multirow{3}{*}{$\begin{array}{l}\text { Blood gas } \\
\text { analyses } \\
\text { variables }\end{array}$} & \multicolumn{9}{|c|}{ Group I $(\mathrm{n}=4)$ Moment } \\
\hline & \multicolumn{3}{|c|}{ Baseline } & \multicolumn{3}{|c|}{ M1 } & \multicolumn{3}{|c|}{ M2 } \\
\hline & $1^{\text {st }}$ Quartile & Median & $3^{\text {rd }}$ Quartile & $1^{\text {st }}$ Quartile & Median & $3^{\text {rd }}$ Quartile & $1^{\text {st }}$ Quartile & Median & $3^{\text {rd }}$ Quartile \\
\hline $\mathrm{PaO}_{2}(\mathrm{mmHg})$ & 389.5 & 403.5 & 414.5 & 336.50 & 349.00 & $356.25^{a}$ & 361.75 & 379.00 & 386.00 \\
\hline $\mathrm{PaCO}_{2}(\mathrm{mmHg})$ & 29.5 & 31.0 & 33.0 & 25.75 & 26.5 & 27.75 & 26.0 & 28.5 & 32.5 \\
\hline $\mathrm{SaO}_{2}(\%)$ & 100.0 & 100.0 & 100.0 & 100.0 & 100.0 & 100.0 & 100.0 & 100.0 & 100.0 \\
\hline $\mathrm{BD}(\mathrm{mEq} / \mathrm{L})$ & -4.00 & -3.0 & -3.0 & -9.0 & -7.5 & $-6.75^{a}$ & -7.75 & -6.5 & -5.75 \\
\hline
\end{tabular}

$\mathrm{kg}$, in bolus IV, twice) and recovered from anesthesia. Among the other animals from this group, one dog presented ventricular fibrillation at seven minutes of outflow occlusion, other dog showed sinus bradycardia and cardiac arrest at six minutes of pulmonary occlusion, followed by ventricular fibrillation after releasing the tourniquet. The last dog had pulseless electrical activity after releasing the occlusion. All dogs received the management for resuscitation attempts. Lidocaine ${ }^{22}$ was administered to the first dog (2mg/kg in bolus IV) and internal electrical defibrillation $(3 \mathrm{~J})$ was performed. The second dog received epinephrine ${ }^{21}(0.01 \mathrm{mg} / \mathrm{kg}$, in bolus IV) for the cardiac arrest, then his heart fibrillated and it was administered lidocaine ${ }^{22}(2 \mathrm{mg} / \mathrm{kg}$ in bolus IV) and electrical shock, but he did not respond. The third dog received epinephrine ${ }^{21}$ $(0.01 \mathrm{mg} / \mathrm{kg}$, in bolus IV twice), without response. All dogs received direct cardiac massage. All attempts of cardiac resuscitation failed, and all three dogs died.

In Group I there was a decrease in $\mathrm{PaO}_{2}$ and $\mathrm{HCO}_{3}{ }^{-}$, and an increase in the base deficit five minutes after the reestablishment of circulation (M1) (Table 1). In the remained dog from Group II $\mathrm{pH}$ and $\mathrm{PaO}_{2}$ decreased and the $\mathrm{PaCO}_{2}$ and base deficit increased after outflow occlusion (Table 2).

The hemodynamic variables and oxygen transport indexes did not change significantly in Group I. Nevertheless, in the dog from Group II, there was an increase in the HR, SAP, DAP, MAP, PAP, PWP, CVP, CO, CI, LVSW,

22 Lidocaine (Lidocaina 2\%, Abbott Laboratórios do Brasil Ltda, São Paulo, SP).

Table 2. Individual values of $\mathrm{pH}, \mathrm{PaO}_{2}, \mathrm{PaCO}_{2}, \mathrm{SaO}_{2}, \mathrm{HCO}_{3}^{-}$, and base deficit (BD) from arterial blood of one dog submitted to eight minutes of outflow occlusion at baseline and five minutes (M1) and 30 minutes (M2) after procedure

\begin{tabular}{lccc}
\hline \multirow{2}{*}{$\begin{array}{l}\text { Blood gas ana- } \\
\text { lyses variables }\end{array}$} & \multicolumn{3}{c}{ Group II $(\mathrm{n}=1)$ Moment } \\
\cline { 2 - 4 } & Baseline & $\mathrm{M} 1$ & $\mathrm{M} 2$ \\
\hline $\mathrm{pH}$ & 7.41 & 7.06 & 7.12 \\
$\mathrm{PaO}_{2}(\mathrm{mmHg})$ & 375.00 & 121.00 & 294.00 \\
$\mathrm{PaCO}_{2}(\mathrm{mmHg})$ & 29.00 & 66.00 & 57.00 \\
$\mathrm{SaO}_{2}(\%)$ & 100.00 & 97.00 & 100.00 \\
$\mathrm{HCO}_{3}^{-}(\mathrm{mEq} / \mathrm{L})$ & 18.00 & 18.00 & 18.00 \\
$\mathrm{BD}(\mathrm{mEq} / \mathrm{L})$ & -4.00 & -15.00 & -13.00
\end{tabular}

RVSW, $\mathrm{DO}_{2}, \mathrm{VO}_{2}$, and $\mathrm{O}_{2}$ ext at $\mathrm{M} 1$, from the baseline. RVSW, $\mathrm{CaO}_{2}$, and $\mathrm{CVO}_{2}$ decreased after eight minutes of circulatory arrest. All values returned to normal 30 minutes after releasing the occlusion (M2) (Table 3).

Table 3. Individual values of hemodynamic variables and oxygen transport indexes from a dog submitted to eight minutes of outflow occlusion at baseline and five minutes (M1) and 30 minutes (M2) after procedure

\begin{tabular}{|c|c|c|c|}
\hline \multirow{2}{*}{$\begin{array}{c}\text { Hemodynamic variables } \\
\text { and oxygen transport } \\
\text { indexes }\end{array}$} & \multicolumn{3}{|c|}{$\begin{array}{c}\text { Group II }(n=1) \\
\text { Moment }\end{array}$} \\
\hline & Baseline & M1 & M2 \\
\hline HR (bpm) & 74.00 & 197.00 & 146.00 \\
\hline $\mathrm{SAP}(\mathrm{mmHg})$ & 103.00 & 270.00 & 92.00 \\
\hline MAP (mmHg) & 78.00 & 235.00 & 70.00 \\
\hline $\mathrm{DAP}(\mathrm{mmHg})$ & 67.00 & 210.00 & 59.00 \\
\hline PAP $(\mathrm{mmHg})$ & 13.00 & 34.00 & 12.00 \\
\hline $\mathrm{PCP}(\mathrm{mmHg})$ & 9.00 & 30.00 & 9.00 \\
\hline CVP $(\mathrm{mmHg})$ & 6.00 & 10.00 & 2.00 \\
\hline $\mathrm{CO}(\mathrm{L} / \mathrm{min})$ & 1.94 & 6.37 & 3.36 \\
\hline SV (ml/beat/Kg) & 26.20 & 32.30 & 23.00 \\
\hline $\mathrm{Cl}\left(\mathrm{L} / \mathrm{min} / \mathrm{m}^{2}\right)$ & 2.59 & 8.27 & 4.36 \\
\hline $\mathrm{SI}\left(\mathrm{ml} / \mathrm{beat} / \mathrm{m}^{2}\right)$ & 35.00 & 42.00 & 29.90 \\
\hline SVRI (dynes.s/cm $\mathrm{cm}^{2}$ ) & 2221.71 & 2174.36 & 1246.45 \\
\hline PVRI (dynes.s/cm5. $\mathrm{m}^{2}$ ) & 123.42 & 38.65 & 55.00 \\
\hline $\operatorname{LVSW}\left(\mathrm{g} \cdot \mathrm{m} / \mathrm{m}^{2}\right)$ & 39.31 & 142.12 & 30.14 \\
\hline RVSW (g.m/m²) & 6.55 & 20.56 & 5.17 \\
\hline $\mathrm{CaO}_{2}(\mathrm{~mL} / \mathrm{dL})$ & 22.60 & 20.80 & 21.45 \\
\hline $\mathrm{CvO}_{2}(\mathrm{~mL} / \mathrm{dL})$ & 19.94 & 12.80 & 19.72 \\
\hline $\mathrm{DO}_{2}\left(\mathrm{~mL} / \mathrm{min} \cdot \mathrm{m}^{2}\right)$ & 415.80 & 1947.00 & 1082.00 \\
\hline $\mathrm{VO}_{2}\left(\mathrm{~mL} / \mathrm{min} \cdot \mathrm{m}^{2}\right)$ & 73.35 & 737.80 & 80.00 \\
\hline $\mathrm{O}_{2}$ ext $(\%)$ & 17.00 & 38.00 & 7.00 \\
\hline Qs/Qt (\%) & 17.35 & 16.7 & 23.30 \\
\hline $\mathrm{SpO}_{2}(\%)$ & 97.25 & 96.00 & 99.00 \\
\hline $\mathrm{EtCO}_{2}(\mathrm{mmHg})$ & 33.62 & 45.00 & 55.10 \\
\hline
\end{tabular}

\section{DISCUSSION}

The anesthetic protocol was efficient for performing all maneuvers and the deaths were not related to the anesthesia but with the time of total circulatory arrest.

The technique of outflow occlusion was feasible and the access to the pulmonary trunk was obtained readily through the left thoracotomy, different from the access to the cava veins to accomplish the inflow occlusion (Orton 1995).

All dogs from Group I survived without clinical alteration, similarly to dogs that underwent five minutes of inflow 
occlusion observed in the study reported by Kwasnicka et al. (2000). All these dogs presenting normal values for the coma scale (Shores 1983) were neurologically normal, which means that 4 minutes of circulatory arrest did not cause apparent neurological damage detectable through clinical evaluation. Histopathologic brain analysis such as Total Brain Cell Death Score could have been performed in dead dogs to determine the extent of apoptosis and necrosis in different brain region (Williams et al, 2007). However histopathologic evaluation was not performed in this study.

In Group II the mortality was $75 \%$. Kwasnicka et al. (2000) reported a mortality of $20 \%$ in dogs submitted to 10 minutes of inflow occlusion. Hunt et al. (1992) observed no mortality and a satisfactory anesthetic recovery in three dogs submitted to eight minutes of circulatory arrest by inflow occlusion. These data might demonstrate that dogs tolerate a shorter period of circulatory arrest by the outflow occlusion in relation to inflow occlusion. One hypothesis to explain these results could be associated with the fact that in case of inflow occlusion the heart maintains empty. Differently, in the outflow occlusion, the right ventricle keeps filled of blood which could increase the wall stress. However, according to Orton (1995), ideally circulatory arrest in a normothermic patient should be less than two minutes, but can be extended to four minutes if necessary. In this study, there was no mortality in the group which underwent four minutes of circulatory arrest.

The remaining dog from Group II did not show clinical or neurological abnormalities after the outflow occlusion. On the other hand, Stopiglia et al. (2001) observed important neurological abnormalities in three dogs that underwent 10 minutes of inflow occlusion. However, in that study, one dog survived without neurological abnormalities, as reported in the present study. In other study, Hunt et al. (1992) observed a normal neurological status in three dogs after 8 minutes of circulatory arrest, by inflow occlusion.

The bradycardia observed in one dog after releasing the pulmonary occlusion might be related to a sudden increase in the blood pressure after reestablishing the circulation, stimulating the baroreceptors to decrease the heart rate, as sometimes observed after fast closure of persistent Ductus arteriosus (Orton 1997). However, bradycardia was also observed during the outflow occlusion in other dog and it could be caused by a decrease in the myocardium oxygen level. On the other hand, two dogs maintained a sinus rhythm. In an eventual open-heart surgery this could difficult the surgical maneuvers, because of the constant cardiac movement. However most of surgeries performed under inflow occlusion are also made with the heart beating, which requires surgeons' training and experience.

The diminished $\mathrm{HCO}_{3}{ }^{-}$and base deficit observed five minutes after releasing pulmonary occlusion in Group I may have occurred as result of metabolic acidosis, secondary to the circulatory and ventilatory arrest (Haskins 1996). Nevertheless, all values of blood gas analysis were normal 30 minutes after releasing the occlusion (M2). Moreover, pulseless electrical activity observed in one dog from Group II after releasing the occlusion may have occurred because of severe myocardial acidosis.

The dog from Group II showed respiratory acidosis and hypoventilation, represented by a rise in the $\mathrm{PaCO}_{2}$ (Haskins 1996). Likewise, Kwasnicka et al. (2000) observed a significant increase in the $\mathrm{PaCO}_{2}$ in dogs after four minutes of circulatory arrest by inflow occlusion.

In the Group I, there were no hemodynamic changes after outflow occlusion. Differently, in the Group II, an increase was observed in the HR, SAP, DAP, MAP, PAP, PWP, CVP, CO, Cl, LVSW, $\mathrm{CaO}_{2}, \mathrm{DO}_{2}, \mathrm{VO}_{2}$, and $\mathrm{O}_{2}$ ext at M1. Stopiglia et al. (1998) observed only a PAP and PWP increase after 5 minutes of inflow occlusion in dogs. The same author reported $\mathrm{DO}_{2}$ and $\mathrm{VO}_{2}$ elevated after 8 minutes of circulatory arrest, corroborating to our findings. Such result may demonstrate a prior oxygen debt due to low blood flow (here caused by the outflow occlusion) and an increment in the oxygen extraction after ischemia, as previously described by Schoemacker \& Parsa (1995). Moreover, $\mathrm{DO}_{2}$ and $\mathrm{VO}_{2}$ are products of cardiac index $(\mathrm{Cl})$ multiplied by oxygen content of arterial blood $\left(\mathrm{CaO}_{2}\right)$ (Schoemacker \& Parsa 1995); therefore, we assumed that the increase in these variables occurred mainly due to the sharp increase in $\mathrm{Cl}$ (once $\mathrm{CaO}_{2}$ decreased at this moment). Simultaneously, $\mathrm{Cl}$ is the cardiac output (CO) divided by body surface area (BSA). Cardiac output depends on the heart rate (HR) and systolic volume (SV). In the study reported here, SV increased only 1.2 times while HR increased 2.66 times, which means that $\mathrm{CO}$ increased mainly by the HR increase, which was probably caused by epinephrine application.

\section{CONCLUSION}

We conclude that outflow occlusion is a feasible surgical procedure for period of 4 minutes of circulatory arrest.

Acknowledgements.- The authors thank Fundação para o Amparo da Pesquisa no Estado de São Paulo (FAPESP) for the financial support, and Silvio Nunes, for the illustration.

\section{REFERENCES}

Abduch M.C.D. 2004. Ecocardiografia, p.287-345. In: Carvalho C.F. (Ed.), Ultra-sonografia em Pequenos Animais. Roca, São Paulo.

Chrisman C.L. 1985. Neurologia dos Pequenos Animais. Roca, São Paulo, p.37-54.

Haskins S. 1996. Monitoring the anesthetized patient, p.409-424. In: Thurmon W.J., Tranquili G. \& Benson G.J. (Ed.), Lumb and Jones' Veterinary Anesthesia. $3^{\text {rd }}$ ed. Williams and Wilkins, Baltimore.

Hunt G.B., Malick R., Bellenger C.R. \& Pearson M.R. 1992. Total venous inflow occlusion in normothermic dog: A study of haemodynamic, metabolic and neurological consequences. Res. Vet. Sci. 52 (3):371377.

Kwasnicka L.K., Stopiglia A.J., Freitas R.R. \& Fantoni D.T. 2000. Avaliação hemogasométrica durante a parada circulatória total - inflow occlusion - aplicada por diferentes períodos em cães sadios. Braz. J. Vet. Res. Anim. Sci. 37(3):234-242. Available at: www.scielo.br/bjvras. 
Lombard C.W. 1984. Normal values of the canine M-mode echocardiogram. Am. J. Vet. Res. 4(10):2015-2018.

Orton E.C. 1995. Small Animal Thoracic Surgery. Williams and Wilkins, Malvern, p.185-186.

Orton E.C. 1997. Surgery of the cardiovascular system, p.575-608. In: Fossum T. (Ed.), Small Animal Surgery. Mosby, St Louis.

Rosner B. 1986. Fundamentals of Biostatistics. $2^{\text {nd }}$ edition. PWS Publishers, Boston. 584p.

Shoemaker W.C. \& Parsa M.H. 1995. Invasive and noninvasive physiologic monitoring, p.252-266. In: Ayres S.M. (Ed.), Textbook of Critical Care. $3^{\text {rd }}$ ed. W.B. Saunders, Philadelphia.

Shores A. 1983. Craniocerebral trauma, p.847-854. In: Kirk R.W. (Ed.), Current Veterinary Therapy. W.B. Saunders, Philadelphia.
Stopiglia A.J., Fantoni D.T., Freitas R.R. \& Kwasnicka L.K. 1998. Hemodynamic evaluation of inflow stasis in dogs. Ann. $23^{\text {rd }}$ Congr. World Small Anim. Vet. Assoc., Buenos Aires., p.737.

Stopiglia A.J., Freitas R.R., Irino E.T., Pogliani F.C., Simões E.A., Kwasnicka K.L., Fantoni D.T. \& Jatene F.B. 2001. Avaliação clínica da parada circulatória total em cães (Canis familiaris). Acta Cirúrg. Bras.16 (4):211-217.

Tilley L.P. 1992. Essentials of Canine and Feline Electrocardiography. $3^{\text {rd }}$ ed. Lea and Febiger, Philadelphia, p.21-39.

Williams J.A., Barreiro C.J., Nwakanma L.U., Lange M.S., Kratz L.E., Blue M.E., Berrong J., Patel N.D., Gott V.L., Troncoso J.C., Johnston M.V. \& Baumgartner W.A. 2007. Valproic acid prevents brain injury in a canine model of hypothermic circulatory arrest: A promising new approach to neuroprotection during cardiac surgery. Ann. Thorac. Surg. 83(2):725-726. 